\title{
LITERASI AGAMA PADA ANAK MELALUI PROGRAM PEMBIASAAN PRAKTIK IBADAH
}

\author{
Abstract: \\ Oleh: \\ Religious literacy of children can be started from studying the religious doctrine \\ Khulusinniyah \\ correctly. These activity of religious literacy can be implemented for children by \\ Moh. Zamili \\ performing a program of habituating worship practices in early childhood education \\ institutions. The implementation of this habituation program must be planned clearly \\ and always evaluated. In its implementation, teachers and children demonstrate \\ Email: \\ niakhulusi@gmail.com \\ fine.zam@gmail.com \\ directly so that it is known correctly the kaifiyat of worship by Islamic doctrine. \\ The main target of this program of practicing worship habituation is that children \\ able to and regularly performing worship as a necessity of daily life. \\ Universitas Ibrahimy \\ Keywords: Religious Literacy, Habitual Program, Worship Practices
}

\section{PENDAHULUAN}

Anak usia dini memiliki karakteristik tertentu yang khas dan tidak sama dengan orang dewasa, mereka selalu aktif, dinamis, antusias, dan selalu ingin mengetahui terhadap apa yang dilihat, didengar, dan dirasakan. Anak usia dini bersifat egosentris, memiliki rasa ingin tahu, unik, kaya dengan fantasi, memiliki daya perhatian yang pendek, dan merupakan masa yang potensial untuk belajar. ${ }^{1}$ Anak usia dini tak berhenti mengeksplorasi dan mempelajari, oleh karena itu jangan pernah menyia-nyiakan pendidikan pada masa keemasannya, karena dalam usia tersebut pendidikan begitu penting untuk masa pengenalan sebelum anak usia dini beralih kejenjang pendidikan selanjutnya.

Pendidikan bagi anak usia dini adalah upaya menstimulasi, membimbing, mengasuh dan memberikan kegiatan pembelajaran yang akan menghasilkan kemampuan dan keterampilan anak. ${ }^{2}$ Berdasarkan Undang-Undang Nomor 20 Tahun 2003 tentang sistem Pendidikan Nasional berkaitan dengan Pendidikan Anak Usia Dini tertulis pada Bab 1 pasal 1 ayat 14 ditegaskan bahwa Pendidikan Anak Usia Dini merupakan upaya pembinaan yang ditunjukkan kepada anak sejak lahir sampai dengan

\footnotetext{
${ }^{1}$ Yuliani Nurani Sujiono, Konsep Dasar Pendidikan Anak Usia Dini, (Jakarta: PT Indeks, 2009), 6.

${ }^{2}$ Yuliani Nurani Sujiono, Konsep Dasar Pendidikan Anak Usia Dini, (Jakarta: PT Indeks, 2009), 1.
}

usia enam tahun yang dilakukan melalui pemberian rangsangan pendidikan untuk membantu tumbuh kembang jasmani dan rohani agar anak memiliki kesiapan dalam memasuki pendidikan lebih lanjut. ${ }^{3}$

Anak usia dini sering kali dikatakan ada pada usia emas (golden age). Pada masa ini seorang anak memiliki potensi yang sangat besar untuk mengoptimalkan seluruh aspek perkembangan yang ada pada dirinya. Ke-enam aspek tersebut adalah aspek fisik motorik, kognitif, bahasa, seni, sosial emosi, serta nilai agama dan moral. Pada rentang usia dari lahir sampai enam tahun inilah, merupakan usia tepat untuk menstimulasi anak agar maksimal dalam ke enam aspek perkembangannya sebagai dasar pembentukan generasi bangsa yang berkualitas dan memiliki kecakapan hidup yang tinggi.

Salah satu aspek perkembangan anak usia dini adalah aspek perkembangan nilai agama dan moral. Pada pengembangan aspek nilai agama dan moral, anak distimulasi melalui pembelajaran di PAUD agar dapat memiliki budi pekerti yang baik dan mengamalkan ajaran agama dengan taat, sesual agama yang dianutnya.

Literasi agama perlu dikenalkan pada anak sejak dini agar anak dapat memiliki pengetahuan dan pemahaman keagamaan yang baik. Literasi

\footnotetext{
${ }^{3}$ Yuliani Nurani Sujiono, Konsep Dasar Pendidikan Anak Usia Dini, (Jakarta: PT Indeks, 2009), 6.
} 
agama pada anak dapat diawali dari ajaran agamanya. Kegiatan literasi agama tersebut bisa dilakukan di PAUD dengan melaksanakan program pembiasaan praktik ibadah. Anak-anak sebaiknya dididik disiplin dalam mengamalkan ibadah sehari-hari sehingga dari segi practical religion teaching diharapkan dapat lebih baik dibandingkan dengan mereka yang tidak memeroleh pembiasaan praktik ibadah di lembaga pendidikan PAUD. Bagi lembaga PAUD yang berbasis agama Islam, maka program pembiasaan praktik ibadah dapat berupa praktik ibadah yang disyariatkan oleh ajaran Islam.

\section{PEMBAHASAN}

\section{Pendidikan Agama Bagi Anak Usia Dini}

Dalam proses pendidikan agama pada anak usia dini, ada beberapa hal yang harus diperhatikan, antara lain:

1. Pembinaan pribadi anak. Orang tua merupakan pembina pribadi pertama dalam hidup anak. Melalui proses pendidikan, orang tua dan guru dapat melakukan pembinaan pada anak melalui Pendidikan formal dan informal agar anak dapat membangun kepribadian yang kuat, sikap mental yang sehat, dan akhlak yang terpuji. Setiap pengalaman yang diperoleh anak melalui penglihatan, pendengaran, maupun perilaku yang diperoleh anak, akan membentuk pembinaan pribadi pada anak

2. Perkembangan agama pada anak. Pengalaman keagamaan pada anak akan membentuk anak pada sikap dan perilaku yang sesuai dengan agama yang dianutnya. Sehingga, Pendidikan agama pada anak usia dini sebaiknya ditanamkan dengan pertumbuhan pribadinya.

3. Pembiasaan pendidikan pada anak. ${ }^{4}$ Dalam menanamkan sikap terpuji pada anak, tidak cukup bila hanya dengan penjelasan saja melainkan perlu adanya proses pembiasaan dan latihan akan membawa anak cenderung pada perilaku yang baik dan meninggalkan perilaku yang kurang baik. Agama akan lebih memiliki arti pada anak apabila dijelaskan dengan cara yang lebih dekat pada anak dalam kehidupan seharihari dan lebih konkret.

\footnotetext{
${ }^{4}$ Sa'dun Akbar, Pengembangan Nilai Agama dan Moral pada Anak Usia Dini, (Bandung; Refika Aditama, 2019), 58
}

Keberagaman pada anak usia dini berkembang melalui pengalaman yang didapat dari lingkungan keluarga, sekolah maupun masyarakat. Pengalaman anak yang bersifat keagamaan akan membawa anak pada sikap, prilaku, dan tindakan yang sesuai dengan ajaran agama ${ }^{5}$

Proses pembelajaran pada anak usia dini hendaknya dilakukan dengan tujuan pemberian konsep-konsep dasar yang memiliki makna bagi anak melalui pengalaman nyata, memberikan pengetahuan baru bagi anak dan memungkinkan anak untuk menunjukkan keaktifan dan rasa ingin tahu (curiousity) secara optimal. Selain itu, untuk terwujudnya pendidikan anak usia dini yang baik harus ada dukungan dengan sumber daya manusia yang memadai. Dengan kata lain guru yang berupa pembimbing dan teladan bagi anakanak wajib memiliki kecakapan yang baik dalam kaitan pembelajaran. Yaitu, bagaimana seorang guru mampu mengajar dengan penuh rasa gembira dan ceria dihadapan anak, serta dapat mengelola sebuah pembelajaran yang aktif, kreatif, dan sangat menyenangkan.

Sumber daya manusia yang baik akan menjadikan kegiatan pembelajaran menjadi mengasyikkan dan menyenangkan sehingga peserta didik tidak akan merasa jenuh dan bosan selama mengikuti pembelajaran. ${ }^{6}$ Dalam proses pembelajaran ini, posisi seorang guru adalah sebagai pendamping, pembimbing, serta fasilitator bagi anak. Proses pendidikan seperti tersebut di atas dapat menyeimbangkan bentuk proses pembelajaran yang hanya berorientasi pada kehendak guru yang hanya menempatkan anak secara pasif dan guru menjadi lebih dominan. Kebergantungan (dependent) anak pada pendidik diawal kehidupannya memang sesuatu yang sangat wajar, tetapi dengan berjalannya waktu ada saatnya dimana anak harus lebih mandiri (independent), sehingga perlu adanya sebuah keseimbangan peran dan pola pengasuhan dari seorang pendidik yang terlalu dominan menjadi lebih demokratis ${ }^{7}$. Proses pendidikan yang demokratis akan lebih memotivasi anak untuk belajar menguasai pengetahuan,

\footnotetext{
${ }^{5}$ Sa'dun Akbar, Pengembangan Nilai Agama dan Moral pada Anak Usia Dini, (Bandung; Refika Aditama, 2019), 56.

${ }^{6}$ Muhammad Fadlillah, Desain Pembelajaran PAUD, (Jogjakarta:Ar-Ruzz Media, 2014), 14.

7 Muhammad Fadlillah, Desain Pembelajaran PAUD, (Jogjakarta:Ar-Ruzz Media, 2014), 2.
} 
keterampilan,dan sikap yang harus dimilikinya. Misalnya saja, karakteristik keagamaan anak usia dini pada usia 5-6 tahun antara lain adalah anak mampu melakukan gerakan ibadah dengan sempurna dan menunjukkan perilaku atas dasar nilai keagamaan ${ }^{8}$. Melalui pendidikan yang demokratis,anak akan lebih termotivasi untuk terlibat dalam pembelajaran agar memiliki karakteristik keagamaan sebagaimana yang disebutkan. Karena melalui pembelajaran yang demokratis, anak tidak merasa monoton dan terbebani tetapi bersama-sama pendidik (guru dan orang tua) mengalami sendiri pembelajaran tersebut dengan suasana yang menyenangkan dan bermakna.

Beberapa cara yang dapat dilakukan oleh orang tua dan guru dalam meningkatkan perkembangan keagamaan anak yaitu melalui:

1. Pemberian contoh. Anak usia dini memiliki sifat suka meniru. Anak cenderung meniru perilaku orang tuanya sebagai lingkungan pertama dalam hidup anak'oleh karena itu, peran orang tua sangat penting dalam mengembangkan keagamaan pada anak, yaitu dengan memberikan contoh yang baik sesuai ajaran agama, misalnya pelaksanaan salat atau membantu sesama manusia.

2. Mengikutsertakan anak dalam kegiatan keagamaan. Pengalaman yang berkesan pada anak dapat diperoleh melalui keterlibatannya dalam kegiatan keagamaan. Kesan khusus anak dalam pengalaman tersebut akan menjadi dasar atau pondasi bagi kepekaan beragama pada anak di kemudian waktu

3. Membiasakan ketaatan beribadah. Ketaatan beribadah pada anak dapat dibiasakan melalui ketepatan waktu, pembiasaan, dan keteladanan dari orang tua. Dengan membiasakan anak untuk beribadah tepat waktu, anak akan mampu memahami waktu-waktu beribadah

4. Membacakan kisah Qurani dan Nabawi. Pembacaan kisah atau dongeng dapat mengasah kemampuan berimajinasi dan sosial emosi anak. Sehingga rasa keagamaan pada anak akan lebih cepat tumbuh serta berkembang dengan baik

\footnotetext{
${ }^{8}$ Sa'dun Akbar, Pengembangan Nilai Agama dan Moral pada Anak Usia Dini, (Bandung; Refika Aditama, 2019), 60
}

5. Mendidik keshalehan social. ${ }^{9}$ Pola Pendidikan keagamaan pada anak tidak dapat dipisahkan dari nilai moral yang berlaku di masyarakat, sehingga pendidikan agama pada anak perlu diaktualisasikan dalam kehidupan sehari-hari .

\section{Ibadah sebagai Ajaran Agama Islam}

Ibadah menurut bahasa artinya taat, tunduk, turut, ikut, dan doa. Dilihat dari pelaksanaanya, ibadah dapat dibagi menjadi tiga, yakni (1) ibadah jasmaniah-rohaniah yaitu ibadah merupakan perpaduan jasmani dan rohani, misalnya salat dan puasa; (2) ibadah rohaniah dan maliah, yaitu ibadah perpaduan rohani dan harta, seperti zakat; (3) ibadah jasmaniah-rohaniah-maliah sekaligus, seperti ibadah haji. ${ }^{10}$

Dilihat dari segi bentuk dan sifatnya, ibadah dapat dibagi dalam lima kategori, yaitu: (1) ibadah dalam bentuk perkataan atau lisan, seperti berdzikir, berdoa, memuji Allah dengan mengucapkan alhamdulillah, dan membaca Alquran; (2) ibadah dalam bentuk perbuatan yang tidak ditentukan bentuknya, seperti misalnya membantu atau menolong orang lain, dan mengurus jenazah; (3) ibadah dalam bentuk kegiatan yang sudah ditentukan wujudnya, seperti salat, puasa, zakat, dan haji; (4) ibadah yang cara dan pelaksanaannya berbentuk menahan diri, seperti puasa dan i'tikaf; (5) ibadah yang sifatnya menggugurkan hak, misalnya memaafkan orang lain yang melakukan kesalahan.

Melihat beberapa bentuk ibadah di depan, dapat dipahami tentang hakikat ibadah adalah menumbuhkan kesadaran pada diri manusia bahwa Ia merupakan insan yang diciptakan Allah yang secara khusus untuk mengabdi kepadanya, sebagaimana firman Allah dalam Alquran surat Az-Zariyat ayat 56 :

$$
\text { وما خلقت الجن والا نس الا ليعبد ون }
$$

Artinya: "Dan aku tidak menciptakan jin dan manusia melainkan untuk mengabdi kepadaku".

\footnotetext{
${ }^{9}$ Sa'dun Akbar, Pengembangan Nilai Agama dan Moral pada Anak Usia Dini, (Bandung; Refika Aditama, 2019), 58

${ }^{10}$ Mohammad Daud Ali, Pendidikan Agama Islam (Jakarta: PT. Raja Grafindo Persada, 2002), 244.
} 
Ajaran Islam membagi ibadah pada ibadah khusus (mabdah) dan ibadah umum. Ibadah mabdah adalah ibadah yang ketentuan pelaksanaannya sudah pasti ditetapkan oleh Allah dan dijelaskan oleh Rasul-Nya, seperti salat, puasa, zakat, dan haji. Sementara ibadah umum yakni semua perbuatan yang mendatangkan kebaikan kepada diri sendiri dan orang lain yang dilaksanakan dengan ikhlas karena Allah. ${ }^{11}$ Dalam ensiklopedi Islam disebutkan bahwa ibadah adalah ajaran Islam berupa pengabdian atau penyerahan diri kepada Allah.

Dalam pengertian yang luas, ibadah itu adalah segala bentuk pengabdian yang ditujukan kepada Allah semata yang diawali oleh niat. Ibadah dalam arti yang khusus ialah suatu upacara pengabdian yang sudah disyariatkan oleh Islam, baik bentuk, cara, waktu, serta syarat rukunnya. Contoh ibadah yaitu salat, zakat, puasa, dan haji. Ketentuan bentuk, cara, waktu serta rukun dan syarat yang sudah digariskan dalam syariat Islam secara doktrin itu, tidak dapat diubah, ditukar, digeser, dan disesuaikan dengan logika dan hasil pemikiran. Perbuatan ibadah itu wajib dikerjakan sesuai dengan petunjuk syariat. Bila menyimpang dan tidak sesuai dengan petunjuk syariat maka perbuatan itu tidak sah dianggap sebagai ibadah yang benar. Yang terpenting dalam ibadah khusus itu ialah ibadah pokok yang tergabung dalam rukun Islam. Cara pelaksanaannya langsung dijelaskan dan dicontohkan oleh Rasulullah ${ }^{12}$.

Suatu hal yang tidak boleh dilupakan dalam pengajaran ibadah ini ialah kegiatan yang mendorong supaya yang diajarkan terampil melaksanakan pekerjaan ibadah itu baik dari segi kegiatan anggota badan maupun dari segi bacaan. Ringkasnya, yang disampaikan itu dapat melakukan ibadah dengan mudah. Selanjutnya hal tersebut memotivasi agar dia senang melakukan ibadah tersebut.

Mengajarkan ibadah bukan hanya sekedar memberikan pengetahuan tentang ibadah saja, tetapi yang lebih penting lagi ialah dapat beribadah dengan lebih baik dan senang melakukan ibadah itu terutama ibadah wajib sehari-hari seperti salat, bersuci, puasa,

\footnotetext{
${ }^{11}$ Zakiyah Daradjat, Metodik Khusus Pengajaran Agama Islam, ( Jakarta: Bumi Aksara, 1995), 247

${ }^{12}$ Zakiah Daradjat, Metodik Khusus Pengajaran Agama Islam, ( Jakarta: Bumi Aksara, 1995), 73.
}

dan lain-lain ${ }^{13}$. Karena ibadah ini termasuk dalam ruang lingkup pendidikan agama Islam, maka rasa keagamaanlah yang perlu ditanamkan lebih dahulu dari materi ibadah itu sendiri, karena dengan situasi tersebut proses pembelajaran tentang praktik ibadah akan dapat berjalan dengan baik.

\section{Program Pembiasaan Praktik Ibadah di PAUD}

Metode pembiasaan merupakan metode pembelajaran yang membiasakan suatu aktivitas kepada seorang anak atau peserta didik. Dalam konteks ini, seorang anak dibiasakan melakukan perbuatan-perbuatan baik atau positif sehingga akan tercermin dalam kehidupan sehari-hari. ${ }^{14}$ Salah satu program pembiasaan yang dapat diimplementasikan pada anak di lembaga PAUD adalah pembiasaan praktik ibadah, yakni program kegiatan PAUD untuk membiasakan dan membisakan anak melakukan praktik ibadah sehari-hari.

Dalam melaksanakan program pembiasaan praktik Ibadah di PAUD dapat dilaksanakan dengan tiga tahap, yakni, perencanaan, pelaksanaan, dan evaluasi.

Pada tahap perencanaan, guru dapat memprogram kegiatan praktik ibadah tersebut dalam perencanaan pembelajaran. Waktu yang digunakan bisa satu kali dalam sepekan, misalnya pada akhir pekan.

Sebelum melaksanakan program tersebut, guru perlu mempertimbangkan beberapa hal dalam perencanaan, yakni :

1. Pemilihan materi ibadah

2. Kemampuan awal anak

3. Ketersediaan waktu

4. Kondisi anak

5. Ketersediaan media yang akan digunakan

6. Dukungan orang tua anak.

Kegiatan praktik ibadah dapat dilaksanakan secara klasikal dan kelompok. Guru dapat membentuk beberapa kelompok anak untuk lebih mendalami kegiatan praktik yang dilakukan, karena salah satu cara untuk mencapai tujuan pembelajaran dengan

\footnotetext{
${ }^{13}$ Zakiah Daradjat, Metodik Khusus Pengajaran Agama Islam, ( Jakarta: Bumi Aksara, 1995), 76.

${ }^{14}$ Muhammmad Fadlillah, Desain Pembelajaran PAUD, (Jogjakarta:Ar-Ruzz Media, 2014), 166.
} 
mudah adalah dengan cara berkelompok dan saling membantu untuk mencapai tujuan pembelajaran. ${ }^{15}$

Strategi pelaksanaan program pembiasaan praktik ibadah tersebut, selain menggunakan metode ceramah, guru juga harus menggunakan metode demonstrasi. Metode demonstrasi menurut Tayar Yusuf, berasal dari kata demonstration yang berarti memperagakan atau memperlihatkan proses kelangsungan sesuatu. ${ }^{16}$ Metode demonstrasi adalah metode mengajar dengan cara memperagakan barang, kejadian, aturan dan urutan melakukan suatu kegiatan, baik secara langsung maupun melalui penggunaan media pembelajaran yang relevan dengan pokok bahasan atau materi yang sedang disajikan. Metode ini cocok digunakan karena memiliki kelebihan seperti perhatian siswa lebih dipusatkan, dan juga langsung mengamati contoh konkret suatu hal. ${ }^{17}$

Metode demonstrasi penting digunakan karena dapat memberikan pengalaman langsung pada setiap proses pembelajaran yang dilakukan. Dalam belajar melalui pengalaman langsung, anak tidak sekedar mengamati, tetapi terlibat langsung dalam perbuatan tersebut sehingga dapat bertanggung jawab terhadap hasilnya. Bukhori :

Rasulullah bersabda dalam hadits riwayat

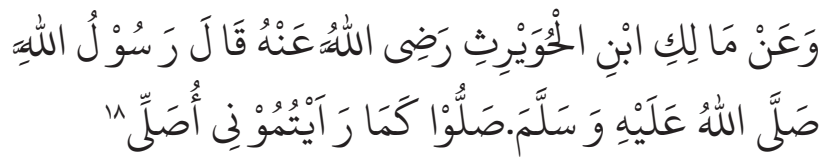

Artinya: Dan dari Malik bin Al-Hawarits: Sesunggubnya Nabi SAW telah bersabda, "Salatlah kamu sebagaimana kamu melihatku salat." (HR: Bukhari)

Hadits tersebut menjelaskan tentang anjuran Rasulullah untuk melihat secara langsung bagaimana beliau salat agar dapat mengetahui dan memahami

\footnotetext{
15 Abd. Muqit \& Djuwairiyah, "Desain Strategi Pembelajaran Menuju Capaian Pembelajaran”, Jurnal Pendidikan Islam Indonesia, Vol. 1, No. 2, (April, 2017), 205.

${ }^{16}$ Tayar Yusuf, Dkk, Metodologi Pengajaran Agama dan Bahasa Arab, (Jakarta: Raja Grafindo 2000), 45.

${ }^{17}$ Muhammad Zein. Metodologi Agama, (Yogyakarta: AK Group dan Indra Buana, t.th.), 177.

${ }^{18}$ Abi Abdillah Muhammad Ibnu Ismail al Bukhari, Shabih Bukhari Juz I, (Semarang: Thoha Putra, t.th), 55.
}

syarat dan rukun salat dengan baik dan benar. Hal tersebut menunjukkan bahwa pembelajaran dengan cara melihat langsung dan melaksanakan langsung akan memberikan pengalaman yang sangat baik dan mudah diingat, sehingga metode demonstrasi sangat tepat untuk menjadi pilihan dalam program pembelajaran praktik ibadah di PAUD, karena akan memudahkan mereka menyerap materi yang diajarkan guru.

Dalam pelaksanaan metode demonstrasi, ada beberapa langkah yang perlu diperhatikan di antaranya ialah, pertama, guru merencanakan dan menetapkan urutan-urutan penggunaan bahan dan alat yang sesuai dengan pekerjaan yang harus dilakukan. Kedua, guru menunjukkan cara pelaksanaan metode demonstrasi. Ketiga, guru menetapkan perkiraan waktu yang diperlukan untuk demonstrasi dan perkiraan waktu yang diperlukan oleh anak-anak untuk meniru. Keempat, anak memperhatikan dan berpartisipasi aktif dalam kegiatan tersebut. Kelima, guru memberikan motivasi atau penguat-penguat yang diberikan, baik bila anak berhasil maupun kurang berhasil. ${ }^{19}$

Basyirudin Usman mengatakan bahwa melalui demonstrasi yang baik berarti guru telah memberikan pengalaman dan keterlibatan yang baik kepada anak sehingga anak dapat mengerti apa yang disampaikan guru dalam sebuah proses pembelajaran ${ }^{20}$ Dalam metode demonstrasi, siswa dirangsang untuk aktif mengamati, menyesuaikan antara teori dengan kenyataan dan mencoba melakukan sendiri. Kelebihan dari metode demonstrasi ini adalah dapat membuat proses pembelajaran menjadi lebih jelas dan lebih konkret, sehingga anak lebih mudah memahami apa yang dipelajari dan proses pembelajaran lebih menarik. Implementasi metode demonstrasi pada pelaksanaan praktik ibadah akan melibatkan anak berpartisipasi aktif dalam setiap pertemuan yang dilakukan, untuk menciptakan pengalaman bagi mereka sehingga dapat mengingat dengan baik setiap proses pembelajaran yang dilakukan.

Pemilihan materi ibadah adalah hal yang harus dilakukan pertama kali. Pada tahap ini, guru dapat memulai praktik tentang materi awal yang

\footnotetext{
${ }^{19}$ Moeslichatun, Metode Pengajaran di Taman Kanak-kanak. (Jakarta : Rineka Cipta, 1999), 123.

${ }^{20}$ Basyirudin Usman, Dkk. Media Pembelajaran. (Jakarta: Delia cipta Utama, 2002), 107
} 
harus dikuasai anak, misalnya pada tahap pertama, materi yang disampaikan adalah tentang wudu. Setelah materi dan praktik wudu tuntas, guru dapat melanjutkan pada program praktik ibadah berikutnya, yakni salat.

Materi yang biasa menjadi program praktik ibadah di PAUD adalah salat. Pada pembahasan tentang salat, guru dapat membaginya menjadi dua pembahasan, yakni salat sendirian dan salat berjemaah. Guru terlebih dahulu menyampaikan teori tentang salat sebelum praktik salat dilaksanakan. Teori tentang salat antara lain meliputi syarat sahnya salat, rukun salat, dan sunnah salat, akan tetapi penekanan materi ada pada rukun salat sebagai materi yang akan dipraktikkan dalam program pembiasaan tersebut.

Esensi pendidikan Islam terletak pada kemampuannya untuk mengembangkan kemampuan peserta didik agar menjadi manusia beriman dan patuh pada perintah Allah. Esensi ini menjadi acuan dari penggunaan metode pembelajaran untuk mencapai tujuan maksimal. ${ }^{21}$ Dalam proses pendidikan Islam, metode memiliki kedudukan signifikan untuk mencapai tujuan pendidikan. Menurut Ismail, metode sebagai seni mentransfer ilmu pengetahuan kepada peserta didik, lebih signifikan dibandingkan materi ${ }^{22}$. Berdasarkan hal ini, maka dalam proses pembelajaran yang dilakukan, guru tidak hanya fokus pada materi saja tetapi pada bagaimana agar materi tersebut dapat diterima dengan baik oleh anak. Dalam penyampaian materi, guru dapat menggunakan gambar dan video pembelajaran agar anak lebih tertarik untuk menyimak sehingga suasana pembelajaran menjadi lebih menyenangkan dan bermakna.

Pembelajaran yang bermakna akan memudahkan anak menyerap materi yang diberikan, sehingga diharapkan akan menumbuhkan sedikit demi sedikit kebiasaan dalam diri anak dalam menerapkan pengetahuan yang didapatnya dari kegiatan pembiasaan tersebut di rumah sehingga kelak mereka tumbuh menjadi insan yang bertakwa.

\footnotetext{
${ }^{21}$ E. Mulyasa, Kurikulum yang Disempurnakan, (Bandung: Remaja Rosdakarya, 2009), 3.

${ }^{22}$ Ismail, Strategi Pembelajaran Agama Islam Berbasis PAIKEM, (Semarang: Rasail, 2008), 2.
}

Islam menganjurkan kita memberikan kemudahan belajar bagi peserta didik agar tujuan pembelajaran bisa tercapai secara optimal. Dalam hal ini guru harus bisa mensetting pembelajaran menjadi proses yang memudahkan anak untuk belajar dengan menciptakan pembelajaran yang menyenangkan, Untuk mewujudkan pembelajaran menyenangkan dan bermakna, guru harus merancang pembelajaran dengan baik, memilih materi yang tepat, dan mengembangkan strategi yang dapat melibatkan anak secara optimal. Dengan pembelajaran menyenangkan, anak akan memusatkan perhatiannya kepada pembelajaran, sehingga time on task terhadap pembelajaran tinggi. Pembelajaran menyenangkan merupakan proses pembelajaran yang didalamnya terdapat kohesi kuat antara guru dan anak tanpa ada perasaan terpaksa (not under pressure). Pola pembelajaran yang terbentuk tidak menjadi pembelajaran searah, melainkan ialah pembelajaran two ways communication, di mana pembelajaran tersebut menekankan pada kesadaran kritis peserta didik terhadap realitas lingkungan sekitarnya serta problem solving. ${ }^{23}$ Dalam pembelajaran menyenangkan, juga akan tercipta pola hubungan yang baik antara guru dan anak. Guru dapat memosisikan diri sebagi mitra belajar anak, dalam hal ini perlu diciptakan suasana demokratis agar tidak ada beban bagi guru dan anak dalam melakukan proses pembelajaran. Anak akan senang belajar bersama guru, berpraktik bersama, dan termotivasi untuk mengamalkannya.

Pembelajaran praktik ibadah mempunyai kedudukan yang urgens dalam kerangka kehidupan beragama anak, Karena dengan mempelajarinya, anak dapat memiliki pengetahuan dan pemahaman tentang bagaimana kaifiat beribadah yang baik, apa yang dibolehkan dan apa pula yang dilarang disaat melakukan ibadah (khususnya salat dan wudhu) sehari-hari. Misalnya saat kegiatan praktik salat, guru harus jeli melihat semua tahapan rukun yang dilakukan anak (qouliyah dan filiyab), sehingga anak dapat mengetahui bagaimana cara salat yang benar. Untuk itu dibutuhkan sebuah pengelolaan pembelajaran yang lebih memberdayakan anak, meningkatkan pengetahuan dan melatih keterampilan mereka, serta menanamkan sikap spiritual dan sosial.

\footnotetext{
${ }^{23}$ Moh. Nawafil dan Junaidi, "Revitalisasi Paradigma Baru Dunia Pembelajaran yang Membebaskan", Jurnal Pendidikan Islam Indonesia, Vol. 4, No. 2, (April, 2020), 215.
} 
Pada usia sekolah, perasaan keagamaan anak dalam tahap perkembangan, yakni perasaan yang menyertai individu ketika menghayati hubungannya dengan Tuhan. Perasaan keagamaan adalah perasaan luhur dalam jiwa manusia, yang mampu menggerakkan hati agar Ia berbuat baik. ${ }^{24}$ Pada masa inilah, guru juga perlu berperan sebagai motivator untuk mengarahkan anak dan membiasakan mereka berbuat baik sesuai ajaran agamanya. Selain sebagai fasilitator yang memudahkan anak memahami materi, peran sebagai motivator urgen dilakukan untuk menanamkan motivasi pada diri anak, sehingga memosisikan ibadah, seperti salat sebagai kebutuhan yang harus dikerjakan dalam kehidupan sehari-hari.

Dalam kegiatan praktik ibadah di PAUD, guru harus dapat mengelola pembelajaran yang tidak mengharuskan anak menghafal fakta-fakta, tetapi sebuah kegiatan yang mendorong anak mengonstruksikan pengalaman di benak mereka sendiri, merangsang dan mendorong anak untuk mampu mengembangkan kreatifitas dan potensipotensi positif pada dirinya.

Anak akan terdorong untuk belajar dan terus belajar jika kondisi pembelajaran dibuat menyenangkan, nyaman dan tidak membosankan. Suasana belajar yang menyenangkan sangat diperlukan karena otak tidak akan bekerja optimal jika perasaan dalam keadaan tertekan. Oleh karena itu saat penyampaian materi, guru perlu menciptakan suasana pembelajaran yang menyenangkan misalnya dengan mengembangkan permainan-permainan, menyelingi dengan tepuk, dan bernyanyi karena anak usia dini harus selalu ceria dalam proses pembelajaran yang dialaminya.

Bimbingan guru dalam program pembiasaan praktik ibadah akan lebih baik jika dapat melibatkan anak dalam pembelajaran, sebagaimana kegiatan dalam active learning. Menurut E. Mulyasa, pembelajaran aktif merupakan pendekatan pembelajaran yang lebih banyak melibatkan aktifitas peserta didik dalam mengakses berbagai informasi dan pengetahuan untuk dibahas dan dikaji dalam proses pembelajaran di kelas, sehingga mereka mendapatkan berbagai pengalaman yang dapat meningkatkan pemahaman dan kompetensinya. ${ }^{25}$

\footnotetext{
${ }^{24}$ E. Mulyasa, Kurikulum yang Disempurnakan, (Bandung: Remaja Rosdakarya, 2009), 60.

${ }^{25}$ E. Mulyasa, Kurikulum yang Disempurnakan, (Bandung:
}

Dalam pembelajaran aktif, guru memosisikan dirinya sebagai fasilitator yang memberikan kemudahan belajar kepada peserta didik. Peserta didik terlibat aktif dan banyak berperan dalam proses pembelajaran, guru memberikan bimbingan dan mengatur proses pembelajaran. ${ }^{26}$ Pelibatan anak untuk menemukan sendiri pengetahuannya juga diimbangi dengan suasana yang menyenangkan, suasana pembelajaran yang membentuk anak senang berkegiatan sehingga kegiatan program pembiasaan dalam penguasaan praktik ibadah dapat berjalan efektif.

Program pembiasaan adalah program kegiatan yang diulang-ulang, sehingga anak dapat menguasainya dan biasa melakukannya. Salah satu karakter anak adalah merasa bosan terhadap sesuatu yang di ulang-ulang, karena mereka lebih menyukai hal baru. Agar kebosanan tidak menjadi problem dalam pelaksanaan program pembiasaan praktik ibadah di PAUD, maka guru tidak boleh monoton dalam menyampaikan materi dan harus menggunakan teknik yang menyenangkan, sehingga dalam hal ini diperlukan teknik komunikasi yang baik antara guru dengan anak.

Menurut Adi Gunawan, ada tiga hal yang perlu dikuasai dalam berkomunikasi, yakni konten, penyampaian, dan konteks. ${ }^{27}$ Konten tidak hanya terdiri dari materi yang akan kita sampaikan akan tetapi mencakup kemampuan pembimbing dalam membangun hubungan dengan santri, membangkitkan motivasi, memberikan nilai tambah dan membangkitakan rasa ingin tahu dan pertanyaan. Penyampaian meliputi penggunaan tubuh sebagai media penyampaian, postur, kontak mata, ekspresi wajah dan gerakan tubuh. Penyampaian juga meliputi kualitas suara dalam menyampaikan materi. Apakah menggunakan nada tinggi, atau rendah sesuai dengan materi yang disampaikan. Konteks meliputi suasana hati atau mood, aturan yang berlaku, pengalaman, pembelajaran terdahulu dan sebagainya. Seorang guru juga harus mempunyai kemampuan berkomunikasi yang baik untuk mempengaruhi situasi yang mendukung proses pembelajaran.

Remaja Rosdakarya, 2009).191.

${ }^{26}$ E. Mulyasa, Kurikulum yang Disempurnakan, (Bandung: Remaja Rosdakarya, 2009), 192.

${ }^{27}$ Adi. W. Gunawan, Genius Learning Strategy, Jakarta: Gramedia, 2014), 156. 
Hal terpenting dalam program praktik ibadah ini adalah adanya motivasi kepada anak agar mereka memiliki motivasi dalam mengerjakan ibadah seharihari. Anak diharapkan tidak hanya mengetahui dan memahami terhadap tata cara wudu dan salat, tetapi juga dapat menjadikan ibadah tersebut sebagai kebutuhan dalam kehidupan mereka, sehingga di manapun mereka berada dapat dengan suka cita dan selalu merasa butuh untuk melaksanakannya.

Pada pelaksanaan program pembiasaan praktik ibadah, guru juga perlu melakukan evaluasi. Norman E. Gronlund mendefinisikan evaluasi sebagai "a systematic process of determining the extent to wich instructional objectives are achieved by pupils" (evaluasi adalah suatu proses yang sistematis untuk menentukan atau membuat keputusan sampai sejauh mana tujuan pengajaran dapat tercapai oleh siswa). ${ }^{28}$ Sebagai evaluator dalam program pembiasaan praktik ibadah, guru perlu melakukan proses evaluasi sejak dari tahap perencanaan dan pelaksanaan. Pada tahap pelaksanaan, proses evaluasi dilakukan terus-menerus setiap pekan untuk mengetahui ketercapaian target dari praktik ibadah yang ditetapkan. Tahap akhir evaluasi adalah pada pekan terakhir pada akhir semester (sesuai target dalam PROTA) dengan melihat sejauh mana penguasaan anak pada materi dan praktik ibadah. Hasil evaluasi terakhir ini selanjutnya menjadi pertimbangan guru tentang ketercapaian target program pembiasaan dan sekaligus sebagai tindak lanjut pada program pembiasaaan berikutnya. Evaluasi dilakukan secara terus-menerus dalam setiap pertemuan yang dilakukan, dan pada akhir pertemuan setelah materi yang disampaikan dinyatakan tuntas.

Sebagai evaluator, guru harus mengumpulkan data tentang keberhasilan program pembiasaan praktik ibadah yang telah dilakukan. Selain untuk menilai keberhasilan anak dalam mencapai tujuan yang telah ditentukan atau keberhasilan anak dalam menyerap materi dan menguasai praktik ibadah yang diajarkan, peran guru sebagai evaluator adalah untuk menilai sejauh mana keberhasilan guru sendiri dalam melaksanakan seluruh program yang telah direncanakan.

Evaluasi proses dapat melalui respon anak saat pelaksanaan program pembiasaan praktik ibadah,

\footnotetext{
${ }^{28}$ M. Ngalim Purwanto, Prinsip-Prinsip dan Teknik Evaluasi Pengajaran, (Bandung : PT Remaja Rosydakarya, 2006), 3.
}

misalnya anak antusias atau tidak dalam menyimak materi dan aktif atau tidak dalam berkegiatan bersama guru serta teman-teman yang lainnya. Sedangkan evaluasi hasil dapat melalui refleksi dan kegiatan recalling pada kegiatan penutup.

Program pembiasaan praktik ibadah dapat dinyatakan berhasil, jika apa yang menjadi target pembiasaan praktik ibadah dapat terpenuhi, yakni penguasaan anak terhadap praktik ibadah sehari-hari (sesuai materi pembiasaan yang diprogram, misalnya wudu, salat, dan salat berjemaah). Seperti anak dapat mempraktikkan bacaan salat dengan benar, anak dapat mempraktikkan gerakan salat dengan benar, kesesuaian bacaan dan gerakan salat, tidak bercanda saat melaksanakan praktik salat, dan sebagainya. Dalam mengevaluasi ketercapaian target pembiasaan praktik ibadah, guru dapat melakukan penilaian dengan menggunakan lembar observasi untuk mengetahui ketercapaian anak pada jenis ibadah yang diajarkan. Dalam hal ini indikator harus jelas dan mencakup seluruh kompetensi yang diajarkan, indikator tersebut harus diurutkan dari hal yang pertama kali harus diucapkan atau dilakukan sesuai urutan ibadah yang dipraktikkan.

Evaluasi tidak dilakukan untuk mengetahui hasil pembiasaan praktik ibadah saja, melainkan harus dilakukan selama proses pelaksanaan pembiasaan praktik ibadah itu sendiri. Karena dengan evaluasi tersebut dapat dilakukan revisi terhadap strategi pelaksanaan pembiasaan praktik ibadah atau sebagai umpan balik pada kegiatan berikutnya.

Evaluasi dalam program pembiasaan praktik ibadah dapat memberikan manfaat di antaranya untuk mengetahui kemajuan dan perkembangan serta keberhasilan anak setelah menjalani kegiatan kegiatan pembiasaan praktik ibadah selama jangka waktu yang telah ditentukan. Hasil evaluasi yang diperoleh adalah untuk memperbaiki tata cara beribadah mereka. Selanjutnya untuk mengetahui tingkat keberhasilan program pembiasaan praktik ibadah. Manfaat lain, untuk keperluan pengembangan dan perbaikan program pembiasaan praktik ibadah yang akan datang.

Untuk menutupi adanya kekurangan durasi praktik karena keterbatasan waktu program praktik ibadah di lembaga PAUD, maka pendalaman tentang 
praktik ibadah dilakukan secara bersinergi antara guru dan orang tua di rumah. Pada kegiatan parenting yang dilakukan, guru dapat mengomunikasikan beberapa hal yang menjadi program pembiasaan di PAUD agar pelaksanaannya dapat didukung oleh orang tua.

Hakikatnya, penanaman nilai agama pada anak adalah tugas utama orang tua, sebagaimana yang tersirat dalam hadits berikut:

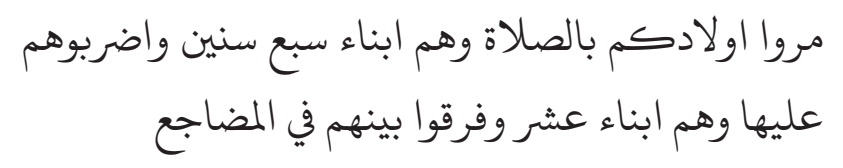

Artinya: Perintabkanlah anak-anakmu untuke melaksanakan salat apabila mereka telah berusia tujub tabun, dan apabila mereka telah berusia sepulub tahun maka pukullah mereka (apabila tidak mau melaksanakan salat itu) dan pisabkanlah tempat tidur mereka. ${ }^{29}$

Faktanya, pendidikan anak di masa dini sering tidak direncanakan dengan baik oleh banyak kalangan, terutama orang tua. ${ }^{30}$ Termasuk juga pendidikan Islam yang seharusnya diajarkan pada anak, sehingga guru perlu mengomunikasikan dengan baik tentang program yang biasa dilakukan di PAUD untuk juga menjadi pembiasaaan di rumah. Dengan adanya pendidikan keagamaan yang bersinergi antara lingkungan PAUD dan lingkungan keluarga maka diharapkan dapat membentuk kepribadian anak yang saleh-saleha.

Orang tua memiliki tanggung jawab besar dalam menanamkan aspek keagamaan pada anak, peran penting orang tua di sini juga melalui keteladanan. Dalam konteks PAUD, metode keteladanan harus dapat ditunjukkan dan dilakukan oleh setiap pendidik, sebab salah satu karakteristik anak usia dini adalah suka meniru.

Anak usia dini ada masa meniru. Dalam proses modelling tersebut, diawali dengan perhatian (attention), penyimpanan (retention), dan fase memproduksi (production). Setelah tahap ini anak dapat termotivasi kembali untuk mengulanginya,

\footnotetext{
${ }^{29}$ Abdullah Nasih Ulwan, Tarbiyah al-Awlad fi al-Islam, Terj. Jamaluddin Miri, (Jakarta; Pustaka Amani, 1999), 54.

${ }^{30}$ Muslimin dan Hosaini, "Konsep Pendidikan Anak Menurut al Qurán dan Hadits", Edupedia: Jurnal Studi Pendidikan dan Pedagogi Islam, Vol. 4, No. 1, (Juli, 2019), 67.
}

sehingga guru dan orang tua harus menjadi contoh yang baik bagi anak. ${ }^{31}$

Pada masa usia dini, semua potensi anak berkembang sangat cepat. ${ }^{32}$ Anak usia dini merupakan individu yang berbeda, unik, dan memiliki karakteristik tersendiri sesuai dengan tahapan usianya. ${ }^{33}$ Dalam hal perkembangan kognisi, anak belajar memecahkan masalah serta berpikir logis tentang apa yang dilihat dan dirasakan. ${ }^{34}$ Dalam hal ini, orang tua sebagai teladan harus memberikan contoh yang baik bagi anak, sehingga anak dapat meniru apa yang dilihatnya, seperti kegiatan ibadah yang biasa dilakukan oleh orang tuanya.

Program pembiasaan yang dikembangkan oleh lembaga PAUD ini, akan menjadi suatu kebiasaan yang konsisten dan merupakan bagian yang tidak dapat terpisahkan dalam kegiatan sehari-hari. Program ini nantinya akan menjadi ciri khas lembaga tersebut. ${ }^{35}$ Program pembiasaan lainnya selain praktik ibadah yang dilaksanakan setiap akhir pekan antara lain dapat berupa kegiatan keagamaan setiap pagi sebelum memulai kegiatan pembelajaran dan kegiatan yang terintegrasi dengan kegiatan pembelajaran. Sebelum memulai pembelajaran, program pembiasaan yang bisa dilakukan seperti membaca surat-surat Alquran, membaca hadits sebagai edukasi bagi anak, membaca Asmaul Husna dan melaksanakan salat Dhuha. Kegiatan pembiasaan yang terintegrasi dengan pembelajaran dapat berupa pembacaan doa-doa yang berhubungan dengan kegiatan sehari-hari dan motivasi guru pada anak untuk berprilaku terpuji berdasarkan nilai-nilai moral dan keagamaan seperti selalu bersyukur, mengucap salam saat bertemu, saling tolong menolong, menghormati yang lebih tua, bersikap sopan santun pada sesama manusia, dan mencintai semua makhluk ciptaan Allah.

\footnotetext{
${ }^{31}$ Khulusinniyah, "Cognitive Development; Mencermati Siklus Pertumbuban Kognitif Anak”, Lisan Al-Hal, Vol. 10, No. 2, (Desember, 2016), 262.

${ }^{32}$ Hariyanto , Pengantar Edutaiment PAUD, Jember: Pena Salsabila, 2013), 6.

${ }^{33}$ E. Mulyasa , Manajemen PAUD, (Bandung : PT Remaja Posdakarya, 2012), 20-21.

${ }^{34}$ Apriyanti Novita Rahayu, Menumbubkan Kepercayaan Diri Melalui Kegiatan Bercerita, (Jakarta: PT. Indeks, 2013), 18.

${ }^{35}$ Sa'dun Akbar, Pengembangan Nilai Agama dan Moral pada Anak Usia Dini, (Bandung; Refika Aditama, 2019), 96
} 


\section{SIMPULAN}

Program pembiasaan praktik ibadah di PAUD dilaksanakan sesuai dengan kebutuhan dan kemampuan anak. Dalam melaksanakan kegiatan praktik, guru perlu memberikan bermacam-macam situasi belajar yang memadai untuk materi yang disajikan, dan menyesuaikannya dengan kemampuan dan karakteristik serta gaya belajar anak. Pelaksanaan program pembiasaan praktik ibadah ada tiga tahap, yakni perencanaan, pelaksanaan, dan evaluasi. Guru harus selalu mengevaluasi pelaksanaan program pembiasaan tersebut untuk mengetahui ketercapaian program dan sebagai tindak lanjut pada pertemuan berikutnya. Selain menggunakan metode ceramah dalam penyampaian materi, guru juga menggunakan metode demonstrasi untuk menjelaskan kaifiyat beribadah secara baik dan benar. Guru harus melibatkan anak secara aktif dalam proses pembelajaran yang menyenangkan dan bermakna, untuk menstimulasi anak agar semangat mengikuti program pembiasaan praktik ibadah di PAUD, sehingga pada akhirnya mereka akan termotivasi untuk membiasakan kegiatan ibadah tersebut di rumah dengan atau tanpa pengawasan dari orang tua.

\section{DAFTAR RUJUKAN}

Akbar, Sa'dun. Pengembangan Nilai Agama dan Moral pada Anak Usia Dini. Bandung; Refika Aditama, 2019.

al Bukhari, Abi Abdillah Muhammad Ibnu Ismail. Shabih Bukhari Jur. I. Semarang: Thoha Putra, t.th.

Ali, Mohammad Daud. Pendidikan Agama Islam. Jakarta: PT. Raja Grafindo Persada, 2002.

Daradjat, Zakiyah. Metodik Khusus Pengajaran Agama Islam. Jakarta: Bumi Aksara, 1995.

Fadlillah, Muhammad. Desain Pembelajaran PAUD. Jogjakarta:Ar-Ruzz Media, 2014.

Gunawan, Adi W. Genius Learning Strategy. Jakarta: Gramedia, 2014.

Hariyanto. Pengantar Edutaiment PAUD. Jember: Pena Salsabila, 2013.

Ismail. Strategi Pembelajaran Agama Islam Berbasis PAIKEM. Semarang: Rasail, 2008.
Khulusinniyah, "Cognitive Development; Mencermati Siklus Pertumbuhan Kognitif Anak", Lisan AlHal, Vol. 10, No. 2, (Desember, 2016).

Moeslichatun. Metode Pengajaran di Taman Kanak-kanak. Jakarta : Rineka Cipta, 1999.

Mulyasa, E. Kurikulum yang Disempurnakan. Bandung: Remaja Rosdakarya, 2009.

Mulyasa, E. Manajemen PAUD. Bandung: PT Remaja Posdakarya, 2012.

Muqit, Abd. \& Djuwairiyah, "Desain Strategi Pembelajaran Menuju Capaian Pembelajaran”, Jurnal Pendidikan Islam Indonesia, Vol. 1, No. 2, (April, 2017).

Muslimin dan Hosaini, "Konsep Pendidikan Anak Menurut al Qurán dan Hadits”, Edupedia: Jurnal Studi Pendidikan dan Pedagogi Islam, Vol. 4, No. 1, (Juli, 2019).

Nawafil, Moh, dan Junaidi. "Revitalisasi Paradigma Baru Dunia Pembelajaran yang Membebaskan", Jurnal Pendidikan Islam Indonesia, Vol. 4, No. 2, (April, 2020).

Purwanto, M. Ngalim. Prinsip-Prinsip dan Teknik Evaluasi Pengajaran. Bandung: PT Remaja Rosydakarya, 2006.

Rahayu, Apriyanti Novita. Menumbubkan Kepercayaan Diri Melalui Kegiatan Bercerita. Jakarta: PT. Indeks, 2013.

Sujiono, Yuliani Nurani. Konsep Dasar Pendidikan Anak Usia Dini. Jakarta: PT Indeks, 2009.

Ulwan, Abdullah Nasih. Tarbiyah al-Awlad fi al-Islam, Terj. Jamaluddin Miri. Jakarta; Pustaka Amani, 1999.

Usman, Basyirudin, Dkk. Media Pembelajaran. Jakarta: Delia cipta Utama, 2002.

Yusuf, Tayar, Dkk. Metodologi Pengajaran Agama dan Bahasa Arab. Jakarta: Raja Grafindo 2000.

Zein. Muhammad. Metodologi Agama. Yogyakarta: AK Group dan Indra Buana, t.th. 